\title{
PENGGUNAAN BAHASA RUANG PUBLIK PADA MASA PANDEMI BAGI INDUSTRI KULINER DESA CANGGU
}

\author{
Ni Nyoman Widani' ${ }^{1}$, Wiya Suktiningsih*2 \\ ${ }^{1}$ Jurusan Seni Kuliner, Politeknik Internasional Bali \\ J1. Pantai Nyanyi, Beraban, Kec. Kediri, Kabupaten Tabanan, Bali, \\ ${ }^{2}$ Jurusan Sastra Inggris, Fakultas Sosial Humaniora,Universitas Bumigora \\ Jl. Ismail Marzuki Cakranegara Mataram, Nusa Tenggara Barat \\ Surel: ${ }^{1}$ wiwinwidani1968@gmail.com, ${ }^{* 2}$ wiya.suktiningsih@ universitasbumigora.ac.id
}

\begin{abstract}
Abstrak
Bali sebagai destinasi wisata yang terkenal diseluruh dunia, mengalami keterpurukan akibat pandemi Covid-19 pada pertengahan tahun 2020. Hal ini juga berdampak pada industri kuliner yang berhubungan dekat dengan sektor pariwisata. Pengelola industri kuliner di masa tatanan new normal berusaha bertahan dengan menerapkan protokol kesehatan sesusai anjuran pemerintah. Bentuk edukasi ataupun himbauan protokol kesehatan diberikan oleh pengelola melalui media poster dan menerapkan 3M. Terkait dengan pengunaan bahasa ruang publik, indikator yang perlu diperhatikan selain penggunaan bahasa, adalah bentuk visual berupa symbol/icon yang ditampilkan bersama melalui media poster sebagai bentuk komunikasi kepada publik. Penelitian ini dilakukan untuk menganalisa bagaimana bentuk penggunaan bahasa ruang publik yang disajikan dan bagaimanakah respon pengunjung/masyarakat terhadap poster yang digunakan oleh pengelola industri kuliner saat ini. Metode penelitian yang digunakan adalah kualitatif deskriptif dengan menggunakan metode pengumpulan data yang dilakukan adalah observasi, survei dan wawancara. Jumlah responden yang digunakan dalam penelitian ini adalah 27 orang yang merupakan masyarakat/pengunjung industri kuliner yang berada di wilayah objek wisata desa Canggu. Dari hasil penelitian ini diperoleh data bahwa pengunjung/masyarakat lokal memberikan respon positif tertinggi sangat setuju dan setuju sebesar $81 \%$ untuk poster 2 , $66 \%$ untuk poster 3, 62.9\% untuk poster 1 dan terakhir 56\% untuk poster 4. Indikator penilaian tersebut dilihat dari, penggunaan bahasa yang digunakan, visual yang ditampilkan dalam poster dan kemudahan responden mencerna informasi yang di tampilkan pada poster. Dari penelitian ditemukan apa saja yang harus diperhatikan dalam menyusun atau membuat poster mengenai protokol kesehatan sehingga mampu menarik pembacanya dan dapat memberikan kenyamanan bagi pengunjung/konsumen industri kuliner. Selain itu hasil penelitian ini diharapkan mampu memberikan masukan kepada pemerintah setempat, sehingga dapat menentukan kebijakan yang terkait dengan penggunaan bahasa ruang publik pada masa pandemic Covid-19.
\end{abstract}

Kata kunci: Penggunaan bahasa ruang publik, industri kuliner, protokol kesehatan, poster, desa Canggu

\begin{abstract}
Bali as a well-known tourist destination throughout the world, experienced a slump due to the Covid-19 pandemic in mid-2020. This also had an impact on the culinary industry related to the tourism sector. Culinary industry managers in the new normal order are trying to survive by implementing health protocols in accordance with government recommendations. The form of education or health protocol appeals provided by the manager through poster media and implementing 3M. Regarding the use of language in public spaces, indicators that need to be considered in addition to the use of language are visual forms in the form of symbols/icons that are displayed together through poster media as a form of communication to the public. This study
\end{abstract}


p-ISSN: 2301-5926 | e-ISSN: 2579 793X was conducted to analyze the form of language use in the public space presented and how the visitors/community respond to the posters used by the culinary industry managers today. The research method used is descriptive qualitative by using data collection methods carried out are observations, surveys and interviews. The number of respondents used in this study were 27 people who were the community/visitors of the culinary industry in the tourist attraction area of Canggu village. From the results of this study obtained data that visitors / local communities gave the highest positive response strongly agree and agree at $81 \%$ for poster 2, 66\% for poster 3, $62.9 \%$ for poster 1 and lastly $56 \%$ for poster 4 . seen from the use of the language used, the visuals displayed in the poster and the ease with which respondents digest the information displayed on the poster. From what research must be considered in compiling or making posters regarding health protocols so that they are able to attract readers and can provide comfort for visitors/consumers of the culinary industry. In addition, the results of this study are expected to be able to provide input to the local government, so that they can determine policies related to the use of language in public spaces during the Covid-19 pandemic.

Keywords: Landscape linguistic, culinary industry, health protocol, poster, Canggu village

\section{A. PENDAhuluan}

Sejak bulan Juli 2020 pemerintah provinsi Bali memutuskan untuk membuka kembali Pariwisata Bali khusus untuk wisatawan lokal dengan mulai menerapkan fase new normal atau tatanan normal baru, agar pariwisata hidup dan bergairah kembali(Subadra, 2021). Sosialilasai adaptasi kebiasaan baru di masa pandemi Covid-19 mulai dilakukan mulai dari tingkatan yang paling bawah yaitu wilayah desa adat dengan membentuk satgas gotong royong yang melibatkan unsur-unsur desa, dinas, kelurahan, babinsa, dan bhabinkamtibmas dan elemen masyarakat. Bentuk edukasi penerapan New Normal dilakukan dengan berbagai cara, seperti baliho, spanduk, poster, iklan dan video. Poster digunakan sebagai salah media edukasi visual yang didesain secara menarik sehingga efektif digunakan dalam proses pembelajaran(Rahmawati et al., 2020). Peningkatan kasus Covid-19 saat ini mendorong pemerintah lebih mengalakan penyampaian informasi/himbauan untuk masyarakat tetap menjalankan protocol kesehatan, melalui media poster atau baliho. Bentuk pengarahan langsung juga dilakukan dengan melibatkan institusi terkait seperti kepolisian, Polisi Pamong Praja, TNI dan instansi lainya turut serta terjun ke masyarakat. Pemerintah saat ini secara resmi menghimbau masyarakat untuk mengurangi aktivitas di luar rumah demi menekan penyebaran virus corona COVID-19 di Indonesia(Utama, Suamba, Sumartana, Waruwu, \& Krismawintari, 2020). Poster yang berisi himbauan tentang protokol kesehatan, ditempatkan pada setiap sudut wilayah publik seperti di tempat kuliner, objek wisata, hotel dan lainnya. Penggunaan bahasa dalam menyampaikan himbauan/informasi tentang protokol kesehatan harus berdaya persuasi, sehingga dapat mempengaruhi masyarakat untuk menerapkan perilaku konsep new normal yang sesuai dengan prokes, khususnya untuk pelaku atau pengelola di bidang 
industry tata boga dengan kata lain kuliner(Pujianto, Vallery, \& Soetanto, 2021). Selain itu pada industry kuliner ditemukan adanya fenomena penggunaan berbagai istilah bahasa Inggris di luar ruang publik yang memperlihatkan sifat modern, optimis dan terbuka, dan menciptakan kepraktisan (Purwanto \& Filia, 2020).

\section{B. KAJIAN TEORI}

Penggunaan bahasa ruang publik pada industri kuliner yang berada di wilayah objek wisata desa Canggu, saat masa pandemic Covid-19 sangat menarik untuk diteliti dimulai dari menganalisa bentuk penggunaan bahasa yang digunakan dalam penyampaian informasi atau himbauan yang terkait protokol kesehatan dan bagaimana respon masyarakat/pengunjung yang membaca poster himbauan tersebut. Penggunaan bahasa pada ruang publik tersebut menjadikan (LL) atau Lanskap Linguistik sebagai kajian yang memberikan simultan dan menganalisis pengaturan sebuah kebijakan penggunaan bahasa pada ranah pendidikan, media, kehidupan sosial ekonomi, dan sebagainya(Aribowo, Rahmat, \& Arif Julianto Sri Nugroho, 2018). Menurut Puzey (2016), lanskap linguistik adalah kajian interdisipliner yang digunakan untuk menganalisa adanya berbagai isu bahasa yang berinteraksi dengan bahasa lain di dalam ruang publik atau umum(Fatmahwati A, 2019). Kajian lanskap linguistik dapat dikatakan kajian yang relatif baru dalam lingkup linguistik terapan, kerangka konsep dalam kajian ini bersinggungan dengan kajian ilmu lain, seperti siolinguistik, multilingualisme, kebijakan bahasa, geografi budaya, semiotik, sastra pendidikan, dan psikologi sosial. Dengan adanya fenomena interaksi bahasa di ruang publik, para linguist dapat menelusuri konstruksi simbolis sebuah ruang dan penggunaan bahasa dalam memediasi relasi sosial dan politik.

Terkait dengan pengunaan bahasa ruang publik, indikator yang perlu diperhatikan adalah bentuk visual berupa symbol/icon yang ditampilkan bersama dengan pengunaan bahasa sebagai bentuk komunikasi kepada publik. Konsep dalam komunikasi mempelajari bagaimana suatu desain komunikasi visual dan pengunaan bahasa yang diaplikasikan dalam diterima oleh pembacanya baik itu kalangan khusus atau umum. Dalam media komunikasi visual dipelajari bagaimana mengelola elemen desain grafis yang bisa terdiri dari gambar/ilustrasi, huruf, warna, komposisi dan layout (Ramadeni \& Soewardikoen, 2017). Dalam penelitian ini, peneliti menganalisa bagaimana pengunaan bahasa dan bentuk visual pada media himbauan yang ada pada industri kuliner. Apakah 
p-ISSN: 2301-5926 | e-ISSN: 2579 793X poster himbauan yang digunakan saat ini mampu mempengaruhi, membujuk dan mengingatkan pembacanya seperti fungsi iklan namun tidak memberikan nilai tambah.

Industri kuliner di provinsi Bali termasuk industri yang banyak diminati para pengusaha dan terkait dekat dengan sektor pariwisata. Perkembangan Bali sebagai destinasi wisata menciptakan kesempatan atau peluang kepada industry kuliner sebagai daya tarik tersendiri (Zahrulianingdyah, 2018). Berdasarkan (Kementrian Pariwisata dan Ekonomi Kreatif, 2019) sub sektor kuliner mendominasi struktur ekonomi kreatif Bali. Industri kuliner banyak bermunculan seiring dengan berkembangnya sector pariwisata, mulai dari level bawah berbentuk warung hingga level atas dengan bentuk café/restoran. Makanan yang disajikan sangat beranekaragam mulai dari makanan ringan (camilan), minuman, hingga makanan pokok. Industri kuliner ini juga turut membantu pemerintahan provinsi Bali untuk melestarikan dan memperkenalkan kuliner tradisional daerah, seperti ayam betutu, lawar bebek, bé guling, lak-lak dan lainnya. Selain mendatangkan pendapatan daerah industri kuliner turut membantu penyerapan dan penyedia lapangan kerja bagi masyarakat. Banyaknya peminat industri kuliner mendorong pengelola warung/café/restoran untuk bersaing dengan cara menyuguhkan berbagai konsep makanan, suasana dan tempat makan yang menarik minat pengunjung. Setiap pengelola industri kulinerpun menyesuaikan makanan dan bentuk pelayanan sesuai dengan target sasaran konsumennya.

Pengelola industri kuliner di masa pandemi Covid-19 mulai menyesuaikan bentuk pelayanan kepada konsumennya dan juga memberikan edukasi penerapan protokol kesehatan di masa New Normal dilakukan dengan berbagai cara salah satunya adalah poster. Bahasa yang digunakan dalam media informasi bervariasi dengan tujuan menarik minat pembaca untuk melaksanakan arahan dari protokol kesehatan. Langkah yang dilakukan salah satunya adalah dengan memberikan edukasi berupa informasi New Normal melalui poster pada ruang publik kuliner pada masa Covid-19 di wilayah objek wisata Desa Canggu. Edukasi himbauan/ untuk taat melakukan protokes juga dilakukan oleh pengelola industry kuliner, pada saat melayani konsumen/pengunjung. Himbauan itu lebih difokuskan pada $3 \mathrm{M}$. mencuci tangan, memakai masker dan menghindari kerumunan. Di depan pintu masuk café/restoran disiapkan wastafel dan sabun untuk mencuci tangan kemudian pengukur suhu badan dan sanitizer. 


\section{METODE PENELITIAN}

Penelitian ini menggunakan kajian Lanskap Linguistik, dimana metode penelitian kualitatif ditempuh untuk memperoleh data dan fenomena yang ada di ruang publik di wilayah objek wisata desa Canggu. Langkah awal adalah melakukan dokumentasi objek Lanskap Linguistik. Secara metodologis, analisis Lanskap Linguistik mengandalkan fotografi dan analisis visual. Pengumpulan data berfokus pada keterlibatan fotografi yang tervisualisasi dari teks yang berada pada tanda-tanda di ruang publik(Aribowo et al., 2018). Ruang lingkupnya adalah tempat-tempat yang secara umum didatangi atau digunakan oleh masyarakat/pengunjung. Penelitian ini menggunakan pendekatan deskriptif kualitatif dan menggunakan data kuantitatif untuk mengukur respon publik terhadap pengunaan poster yang berupa informasi/himbauan terkait prokes dalam bentuk kusioner(Putra, Mahardhika, \& Putro, 2019)(Putra, Mahardhika, \& Putro, 2019)(Putra, Mahardhika, \& Putro, 2019)(Putra, Mahardhika, \& Putro, 2019). Data yang digunakan dalam penelitian ini berdasarkan hasil wawancara dan survey terhadap 27 responden masyarakat/pengunjung yang berada di daerah objek wisata Desa Canggu.

Tabel 1 Profil Jenis Kelamin Responden

\begin{tabular}{lcc}
\hline Jenis Kelamin & Jumlah & Prosentase \\
\hline Pria & 13 & $48 \%$ \\
\hline Wanita & 14 & $52 \%$ \\
\hline Jumlah & \multicolumn{2}{c}{ 27 Orang } \\
\hline
\end{tabular}

Tabel 2 Profil Umur Responden

\begin{tabular}{ccc}
\hline Usia & Jumlah & Prosentase \\
\hline $21-40$ & 15 & $55.6 \%$ \\
\hline $41-60$ & 11 & $40.7 \%$ \\
\hline $61-80$ & 1 & $3.7 \%$ \\
\hline
\end{tabular}

Tabel 3 Profil Pendidikan Responden

\begin{tabular}{ccc}
\hline Pendidikan & Jumlah & Prosentase \\
\hline Tidak Sekolah & 0 Orang & $0 \%$ \\
\hline SD - SMA & 5 Orang & $18.5 \%$ \\
\hline D1 - D4 & 7 Orang & $25.9 \%$ \\
\hline S1 & 8 Orang & $29.6 \%$ \\
\hline S2 & 7 Orang & $25.9 \%$ \\
\hline
\end{tabular}

Jenis data dalam penelitian ini adalah data kualitatif yang disimpulkan dari hasil survey berupa kusioner dan wawancara(Suktiningsih, 2017). Kuesioner yang digunakan untuk mengetahui respon pengunjung dan masyarakat dalam bentuk kusioner yang menggunakan skala Likert. Jenis skala Likert, yaitu model kuesioner dengan jenis pertanyaan yang jawabannya Sangat Setuju (SS), Setuju (S), Netral (N), Tidak Setuju (TS), dan Sangat Tidak Setuju (STS), dengan skala terbesar yaitu lima sampai terkecil satu untuk jawaban tiap pertanyaan(Widani \& Suktiningsih, 2020). 


\section{HASIL DAN PEMBAHASAN}

Pada masa pandemi Covid-19 sejak awal tahun 2020 seluruh industri wajib memenuhi protokol kesehatan sesuai dengan ajuran pemerintah, tidak terkecuali industri kuliner seperti kafe dan restoran. Pihak pengelola usaha di industri kuliner turut adil dan bertanggung jawab untuk pencegahan penularan virus Covid-19. Oleh karena itu pengelola usaha kuliner harus memastikan semua pengunjung atau konsumennya mematuhi aturan kesehatan yang dikeluarkan pemerintah. Salah satu langkah yang dilakukan oleh pengelola adalah dengan menempelkan poster himbauan protokol kesehatan yang sesuai dengan aturan pemerintah dan membuat konsep pelayanan dan tempat makan yang memiliki jarak aman antar konsumen/pengunjung restoran tersebut. Penelitian ini dilakukan pada industri kuliner di daerah objek wisata Desa Canggu, Kuta Utara, Badung, Bali. Observasi dan wawancara dilakukan pada industry kuliner yang terletak dekat dengan objek wisata Echo beach - Canggu. Berdasarkan lokasi restoran, mayoritas konsumen/pengunjungnya adalah wisatawan asing sehingga konsep restoran tersebut disesuaikan dengan budaya luar/asing. Ditemukan bahwa poster himbauan yang digunakan oleh café/restaurant dominan menggunakan bahasa Inggris. Berikut adalah bentuk himbauan yang digunakan :

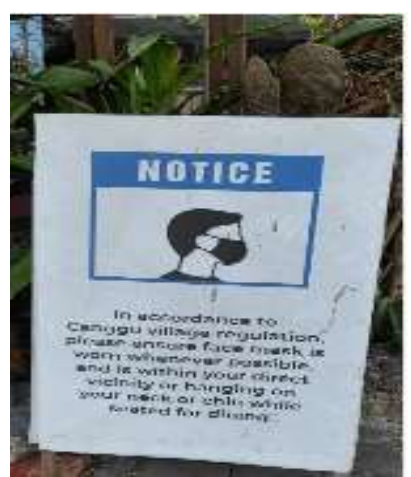

Data 1

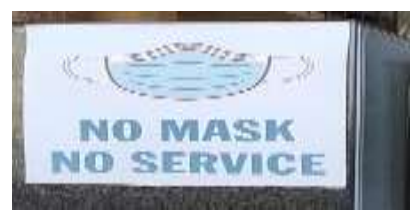

Data 2

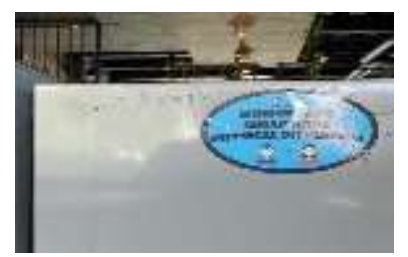

Data 3

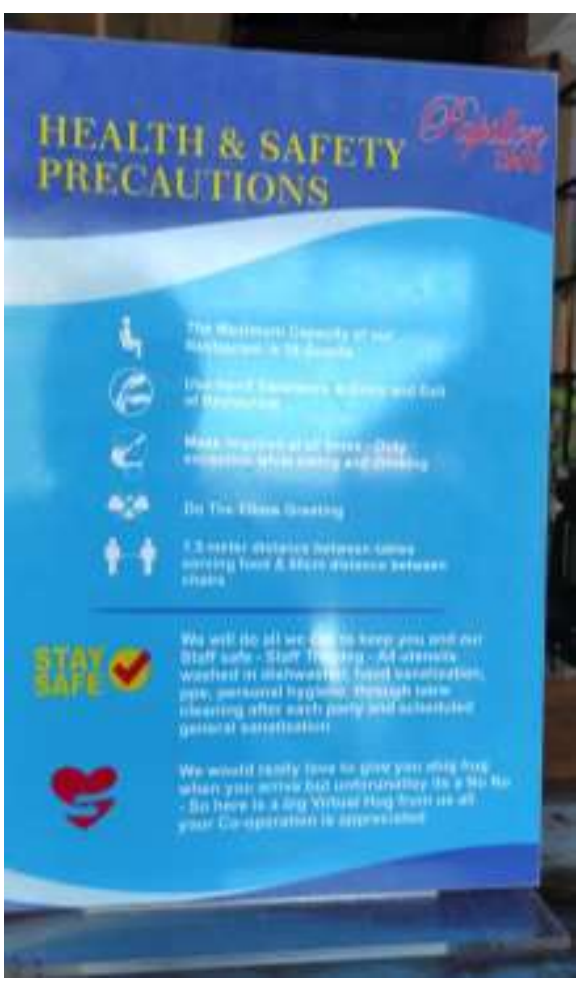

Data 4 
Data 1

\begin{tabular}{|c|c|c|}
\hline $\begin{array}{l}\text { Jenis } \\
\text { Bahasa }\end{array}$ & & Bahasa Inggris \\
\hline & : & NOTICE \\
\hline Headline & & $\begin{array}{l}\text { Bentuk pemberitahuan yang meminta pengunjung/konsumen untuk } \\
\text { memperhatikan Body/badan himbauan. }\end{array}$ \\
\hline $\begin{array}{l}\text { Body } \\
\text { Copy }\end{array}$ & : & $\begin{array}{l}\text { "in accordance to Canggu village regulation, please ensure face mask } \\
\text { is worn whenever possible, and is within your directivicinty or hanging } \\
\text { on your neck or chin while seated for dining." } \\
\text { Kalimat diatas menggunakan kalimat imperative/kalimat perintah atau } \\
\text { permintaan. Kalimat permintaan yang ditampilkan bertujuan agar } \\
\text { pembaca/pengunjung untuk mengikuti peraturan yang diterapkan oleh } \\
\text { Desa Canggu untuk menggunakan masker dan meletakan masker dekat } \\
\text { dengan jangkauan pengunjung ketika melakukan aktivitas makan. }\end{array}$ \\
\hline $\begin{array}{l}\text { Tanda } \\
\text { Visual }\end{array}$ & : & $\begin{array}{l}\text { Ikon manusia menggunakan masker dengan warna hitam berjenis } \\
\text { kelamin laki-laki. Ikon manusia tersebut sebagai model atau tanda yang } \\
\text { terdapat pada poster di atas, ditampilkan untuk mewakili berbagai } \\
\text { status sosial, etnis dan profesi di masyarakat. Hal demikian } \\
\text { mengandung kemiripan visual dan dapat dikenali oleh audien atau } \\
\text { masyarakat (Budiman, 2011). Kemiripan visual manusia yang } \\
\text { menggunakan masker menyampaikan pesan tentang peringatan dari } \\
\text { Desa Canggu yang menekankan penggunaan masker saat berada di } \\
\text { kawasan desa dan menghimbau masker tidak boleh jauh dari anggota } \\
\text { badan tamu yang makan di area desa Canggu. Terkait dengan warna } \\
\text { hitam pada visual manusia menyimbolkan kekuatan dengan penuh } \\
\text { percaya diri dan dimaknai sebagai sebuah perlindungan. Pesan yang } \\
\text { disampaikan melalui visual ikon manusia berwarna hitam dimaknai } \\
\text { sebagai sebauah kemiripan visual yang memperkuat pesan penggunaan } \\
\text { masker di area tersbut untuk melindungi diri dan orang -orang yang } \\
\text { dating berkunjung di desa Canggu. }\end{array}$ \\
\hline Layout & : & $\begin{array}{l}\text { Layout yang digunakan berbentuk persegi empat dengan frame } \\
\text { berwarna biru. Selain itu komposisi menggunakan prinsip } \\
\text { keseimbangan simetri, karena bertujuan untuk memusatkan perhatian } \\
\text { pada pesan yang disampaikan melalui visual maupun verbal. Frame } \\
\text { berwarna biru menunjukan makna sesitifitas jika tidak menggunakan } \\
\text { masker, dan memberi kepercayaan terhadap pentingnya informasi yang } \\
\text { disampaikan melalui poster yakni tentang wajib menggunakan masker. } \\
\text { Kepercayaan terhadap masyarakat atau konsumen yang datang di desa } \\
\text { Canggu. }\end{array}$ \\
\hline Komunikasi & . & $\begin{array}{l}\text { Himbauan dalam poster data 1, masyarakat desa Canggu yang } \\
\text { memperhatikan kesiapan dan ketegasan penerapan protocol kesehatan } \\
\text { dalam masa pandemic covid-19. Masa pandemic digambarkan dalam } \\
\text { visual penggunaan masker dengan menggunakan frame warna biru } \\
\text { untuk memastikan pentingnya masker di masa pandemic covid-19. } \\
\text { Oleh karena itu, penggunaan masker di area desa Canggu diwajibkan } \\
\text { bagi para pengunjung atau tamu. Hal demikian bertujuan untuk } \\
\text { mengurangi atau memutus rantai penyebaran covid-19. }\end{array}$ \\
\hline
\end{tabular}

Data 2

\begin{tabular}{|lll|}
\hline $\begin{array}{l}\text { Jenis } \\
\text { Bahasa }\end{array}$ & $:$ & Bahasa Inggris \\
\hline Headline & $:$ & - \\
\hline
\end{tabular}




\begin{tabular}{|c|c|c|}
\hline Body Copy & : & $\begin{array}{l}\text { NO MASK NO SERVICE } \\
\text { Kalimat diatas menggunakan kalimat imperative/kalimat peringatan. } \\
\text { Kalimat peringatan yang ditampilkan bertujuan untuk menyatakan } \\
\text { peringatan kepada pembaca/pengunjung jika mereka tidak } \\
\text { menggunakan masker maka tidak akan mendapatkan pelayanan oleh } \\
\text { pihak café/restoran. }\end{array}$ \\
\hline $\begin{array}{l}\text { Tanda } \\
\text { Visual }\end{array}$ & : & $\begin{array}{l}\text { Ikon masker dengan warna biru menampilkan kesan damai ketika } \\
\text { menyampaikan peringatan kepada pengunjung/konsumen dari } \\
\text { café/restaurant. Bentuk sikap tegas dari pengelola dapat dilihat dari } \\
\text { peringatan yang menyatakan bahwa pengelola café tidak akan } \\
\text { memberikan pelayanan kepada konsumen yang tidak mengunakan } \\
\text { masker, namun dengan menggunakan warna biru pada masker pesan } \\
\text { konteks penyampaian pesan tersebut memberikan kesan damai dan } \\
\text { tenang. }\end{array}$ \\
\hline Layout & $\cdot$ & $\begin{array}{l}\text { Layout yang digunakan berbentuk persegi empat dengan frame } \\
\text { berwarna biru. Selain itu komposisi menggunakan prinsip } \\
\text { keseimbangan simetri, karena bertujuan untuk memusatkan perhatian } \\
\text { pada pesan yang disampaikan melalui visual maupun verbal. Frame } \\
\text { berwarna biru menunjukan makna sesitifitas jika tidak menggunakan } \\
\text { masker, dan memberi kepercayaan terhadap pentingnya informasi yang } \\
\text { disampaikan melalui poster yakni tentang wajib menggunakan masker } \\
\text { di area café/restoran. }\end{array}$ \\
\hline Komunikasi & & $\begin{array}{l}\text { Himbauan dalam poster data } 2 \text {, menampilkan ketegasan dari pihak } \\
\text { pengelola industry kuliner dalam hal ini Café Dojo Restaurant dalam } \\
\text { upayanya melakukan penerapan protocol kesehatan dalam masa } \\
\text { pandemic covid-19. Masa pandemic digambarkan dalam visual } \\
\text { penggunaan masker dengan menggunakan frame warna biru untuk } \\
\text { memastikan pentingnya masker di masa pandemic covid-19. Oleh } \\
\text { karena itu, penggunaan masker di area café /restaurant diwajibkan bagi } \\
\text { para pengunjung atau tamu. Hal demikian bertujuan untuk mengurangi } \\
\text { atau memutus rantai penyebaran covid-19. }\end{array}$ \\
\hline
\end{tabular}

Data 3

\begin{tabular}{|c|c|c|}
\hline $\begin{array}{l}\text { Jenis } \\
\text { Bahasa }\end{array}$ & & Bahasa Indonesia dan Bahasa Inggris \\
\hline Headline & $:$ & - \\
\hline Body Copy & : & $\begin{array}{l}\text { Mohon Jaga } \\
\text { Jarak Anda } \\
\text { Physical distancing } \\
\text { Kalimat diatas menggunakan kalimat imperative/kalimat permintaan. } \\
\text { Kalimat permintaan yang ditampilkan bertujuan agar pengunjung café } \\
\text { dojo untuk menjaga jarak antar pengunjung dengan minimal jarak } 2 \mathrm{M} \text {. } \\
\text { Penggunaan bahasa Indonesia "mohon anda jaga jarak" memiliki } \\
\text { konteks yang sama dengan "physical distancing". Dimasa pandemic } \\
\text { Covid-19 pengunaan istilah-istilah bahasa Inggris sering sekali } \\
\text { digunakan dalam berbagai situasi oleh pemerintah ataupun masyarakat } \\
\text { umum, baik itu secara verbal maupun non-verbal. }\end{array}$ \\
\hline $\begin{array}{l}\text { Tanda } \\
\text { Visual }\end{array}$ & $:$ & $\begin{array}{l}\text { Ikon dua manusia berjenis kelamin laki-laki dan perempuan yang } \\
\text { diikuti teks bertulisan mohon jaga jarak physical distancing. layout } \\
\text { dengan menekankan kesimbangan simetris bentuk lingkaran yang } \\
\text { mengesankan pada perhatian terpusat pada pesan iklan tersebut. Hal } \\
\text { demikian bersifat ikonik, karena gambar di atas mempresentasikan } \\
\text { meniru bahkan memiliki keserupaan dengan objek yang diacunya. } \\
\text { Bentuk masker dan manusia tersebut menandakan bahwa penggunaan } \\
\text { masker dan menjaga jarak hanya untuk manusia. }\end{array}$ \\
\hline Layout & & $\begin{array}{l}\text { Layout yang digunakan berbentuk lingkaran dengan frame berwarna } \\
\text { hitam memberikan kesan formal, hal itu berdasarkan aturan pemerintah }\end{array}$ \\
\hline
\end{tabular}




\begin{tabular}{|c|c|c|}
\hline & & $\begin{array}{l}\text { dalam penerapan protokol kesehatan yang telah ditetapkan. Selain itu } \\
\text { komposisi menggunakan prinsip keseimbangan simetri, karena } \\
\text { bertujuan untuk memusatkan perhatian pada pesan yang disampaikan } \\
\text { melalui visual maupun verbal. Warna biru menunjukan makna } \\
\text { sensitifitas dan pentingnya untuk menjaga jarak dengan pengunjung } \\
\text { lain yang berada di area Café/restoran. }\end{array}$ \\
\hline Komunikasi & & $\begin{array}{l}\text { Poster data 3, menampilkan ketegasan dari pihak pengelola } \\
\text { menerapkan protokol kesehatan yang telah ditetapkan oleh pemerintah } \\
\text { yaitu selain menggunakan masker juga menjaga jarak wajib dilakukan } \\
\text { untuk mencegah terjadinya penularan virus dan memutus rantai } \\
\text { penyebaran covid-19. }\end{array}$ \\
\hline
\end{tabular}

\section{Data 4}

\begin{tabular}{|c|c|c|}
\hline Jenis Bahasa & & Bahasa Inggris \\
\hline Headline & : & $\begin{array}{l}\text { Health and Safety } \\
\text { Precautions } \\
\text { Pada headline menunjukan tujuan dari pesan yang akan disampaikan di } \\
\text { body copy/badan poster. Tujuan dari poster ini adalah untuk kesehatan } \\
\text { dan keselamatan pengunjung Papillon café. Pada baris selanjutnya } \\
\text { adalah pernyataan tindakan pencegahan yang wajib dilakukan } \\
\text { pengunjung untuk mencapai tujuan yaitu kesehatan dan keselamatan } \\
\text { dimasa pandemic Covid-19 }\end{array}$ \\
\hline & $:$ & $\begin{array}{l}\text { The maximum Capacity of our restaurant is } 18 \text { guests. } \\
\text { Kalimat diatas adalah kalimat deklaratif/pernyataan dari pengelola } \\
\text { bahwa kapasitas pengunjung adalah } 18 \text { orang. Penentuan kapasitas } \\
\text { tersebut bertujuan untuk menjaga jarak antar pengunjung dan pegawai } \\
\text { dalam area café, sehingga memenuhi batas social distancing antar } \\
\text { pengunjung dengan jarak } 1-1.5 \text { meter. Hal ini bertujuan agar tidak } \\
\text { terjadi kontak fisik dan penyebaran droplet (percikan yang terjadi saat } \\
\text { batuk dan bersin). } \\
\text { Use Hand Sanatizers at Entry and Exit of Restaurant } \\
\text { Kalimat diatas menggunakan kalimat imperative/kalimat permintaan. } \\
\text { Kalimat permintaan kepada pengunjung untuk menggunakan hand } \\
\text { sanatizers ketika masuk dan keluar dari area café. Penggunaan hand } \\
\text { sanatizers bertujuan untuk membersihkan tangan dan mencegah } \\
\text { terjadinya penularan Virus Covid-19. }\end{array}$ \\
\hline
\end{tabular}

Body Copy

Mask required at all times - Only exception while eating and drinking Kalimat diatas adalah kalimat imperative yang bertujuan untuk meminta pengunjung café untuk selalu menggunakan masker kecuali disaat makan dan minum.

\section{Do The Elbow Greeting}

Kalimat diatas adalah kalimat imperative yang bertujuan untuk meminta pengunjung café untuk tidak melakukan greeting dengan cara mencium pipi atau berjabat tangan. Dimasa pandemic ini hal itu sangatlah dilarang karena akan mempermudah penularan Virus Covid19. The elbow Greeting adalah cara lain untuk menyapa seseorang yaitu dengan menyentukan bagian siku luar dengan mitra tuturnya. Cara tersebut lebih aman dari segi kesehatan.

1,5 meter distance between tables serving food \& $60 \mathrm{~cm}$ distance between chairs

Kalimat tersebut adalah kalimat deklaratif/pernyataan bahwa jarak antara meja yang digunakan untuk menyajikan makanan adalah 1,5 
p-ISSN: 2301-5926 | e-ISSN: 2579 793X

meter dan jarak meja dengan kursi adalah $60 \mathrm{~cm}$. Hal tersebut adalah standard operation procedure (SOP) untuk pengelola usaha kuliner untuk menghadapi era normal baru.

We will do all we can to keep you and our staff safe - staff training = all utensils washed in dishwasher, hand sanatization, ppe, personal hygiene, through table cleaning after each party and schedulled general sanitization.

Kalimat diatas termasuk kalimat deklaratif yang merupakan pernyataan dari pengelola café, dengan bersedia melakukan semua cara untuk menjaga kesehatan atau keamanan pengunjung, staf tetap dan staf training yang berada di area café. Selain itu juga pengelola menyatakan langkah-langkah yang dilakukan saat mengelola café disaat pandemic dan di saat new normal adalah dengan cara mencuci semua peralatan dengan mesin pencuci piring, sanitasi tangan, ppe, kebersihan pribadi, melalui pembersihan meja setelah setiap pesta dan sanitasi umum terjadwal. Langkah-langkah tersebut dilakukan sebagai usaha pengelola usaha kuliner dengan tujuan untuk kesehatan dan keselamatan semua orang di area Padillon café.

We would really love to give you a big hug when you arrive but unfortunately, it's a no no - so here is virtual hug from us all your cooperation is appreciated

Kalimat diatas adalah kalimat deklaratif yang merupakan pernyataan atau keinginan dari pengelola café untuk menyambut setiap pengunjung ketika datang ke area café, namun hal tersebut tidak mungkin dilakukan karena akan memicu terjadinya penularan Virus Covid-19. Oleh karena itu pengelola menyatakan dengan poster inilah bentuk pelukan virtual dari pengelola café kepada pengunjung, pengelola Papillon café sangat menghargai semua bentuk kerjasama pengunjung untuk taat aturan yang telah ditetapkan.

Tanda Visual

1. Terdapat ikon manusia yang sedang duduk, diinterprestasikan sebagai jumlah manusia yang ada di area café.

2. Ikon dua tangan yang satu sedang menekan hand sanitizer dan tangan satunya lagi terbuka menunggu tetesan hand sanitizer keluar. Hal tersebut menginterpretasikan wajibnya pegunaan hand sanitizer bagi semua orang yang berada di area café.

3. Ikon bagian kepala dan muka yang tertutup masker adalah bentuk interpretasi penggunaan masker di area wajah.

4. Ikon dua tangan yang sedang berjabat tangan dan beri tanda silang berwarna merah adalah bentuk intepretasi larangan bagi orang yang ada di area café untuk berjabat tangan.

5. Dua ikon manusia yang di beri jarak dengan tanda panah bolak-balik dan semua ikon tersebut berwarna putih, hal ini adalah bentuk intrepretasi bahwa semua orang wajib menjaga jarak antara pengunjung ataupun pengelola café.

6. Serta terdapat tanda centang berwarna merah adalah bentuk kepastian bahwa dengan melaksanakan aturan yang telah ditetapkan oleh pengelola café akan menjaga keselamatan semua orang yang ada di area café.

7. Bentuk hati berwarna merah yang dibaluti dua tangan adalah bentuk interpretasi rasa cinta pengelola café kepada semua orang yang ada di dalam area café dan penghargaan kepada semua bentuk kerjasama pengunjung untuk taat aturan yang telah ditetapkan. 


\begin{tabular}{|c|c|c|}
\hline & & $\begin{array}{l}\text { Ikon-ikon yang tersebut mempresentasikan sebuah pesan yang } \\
\text { mengarah pada kemiripan bentuk atau visual dengan sasaran yang } \\
\text { dituju. Pesan verbal dan pesan visual yang terkandung dalam karya di } \\
\text { atas, merupakan interpretasi dari makna ikon dari sasaran yang dituju. } \\
\text { Upaya penyampaian pesan yang mengarah pada sesitifitas pada masa } \\
\text { atau kondisi pandemic covid-19, sehingga penerapan protocol kesehatan } \\
\text { selalu disampaikan melalui media komunikasi visual di berbagai tempat. } \\
\text { Hal demikian yang digambarkan dengan ikon yang ada pada poster di } \\
\text { atas. Melalui bentuk dan tata letak asimetris, namum masih } \\
\text { menampilkan kesan seimbang antara penempatan gambar dan teks. } \\
\text { Selain itu gerakan garis lengkung berwarna putih mengkomunikasikan } \\
\text { pesan yang dinamis dalam menyampaikan pesan tentang kesehatan atau } \\
\text { cara-cara mengatasi penyebaran covid-19. }\end{array}$ \\
\hline Layout & $:$ & $\begin{array}{l}\text { Layout pada visual poster tersebut mengambar keseimbangan antara } \\
\text { tata letak gambar dan teks serta merikan kesan dengan background } \\
\text { warna biru dan tekstur garis lengkung yang lembut. Warna biru } \\
\text { menunjukan makna sensitifitas dan pentingnya untuk melaksanakan } \\
\text { standard operation procedure (SOP) untuk pengelola usaha kuliner } \\
\text { dalam menghadapi era normal baru. Dengan tujuan untuk menjaga } \\
\text { kesehatan dan keselamatan di masa pandemic Covid-19. }\end{array}$ \\
\hline Komunikasi & & $\begin{array}{l}\text { Poster data } 4 \text {, menampilkan bagaimana pihak pengelola Padillon café } \\
\text { dengan detail menyampaikan langkah-langkahnya dalam menerapkan } \\
\text { protokol kesehatan yang telah ditetapkan oleh pemerintah, dengan } \\
\text { tujuan untuk menjaga kesehatan dan keselamatan semua orang yang } \\
\text { ada di area cafe. Fenomena tentang wabah covid-19 ini belum ada } \\
\text { ujungnya, akan tetapi upaya penyampaian pesan selalu disampaiakan } \\
\text { oleh berbagai kalangan. Penerapan } 3 \mathrm{M} \text { di kalangan masyarakat seperti } \\
\text {; mencuci tangan, menggunakan masker dan menjaga jarak. Kesan } \\
\text { yang presentasikan dari warna background pada poster di atas } \\
\text { memberikan pesan sehat dan keadaan sensitive jika tidak melakukan } 3 \\
\text { hal demikian. Selain itu, warna biru yang digunakan mengesankan } \\
\text { suasana ketenangan bagi masyarakat tentang keadaan dalam masa } \\
\text { pandemic covid-19. Oleh karena itu, ikon, warna dan hal terkait pada } \\
\text { poster tersebut, semuanya mengarah pada pesan tentang ketenangan } \\
\text { mengahadapi masa pandemic covid-19 dengan menerapkan 3M. }\end{array}$ \\
\hline
\end{tabular}

\section{Respon Masyarakat/Pengunjung dari Penggunaan Bahasa Ruang Publik}

Untuk mengetahui respon dari masyarakat/pengunjung yang industry kuliner yang

berada di wilayah objek wisata desa Canggu, peneliti melakukan survei dan wawancara. Berdasarkan hasil survei dari 27 responden memberikan respon kepada 4 data poster yang ditampilkan pada kusioner yang disebarkan. Berdasarkan hasil survei melalui kusioner diperoleh data sebagai berikut : 
1. Daya tarik poster 1

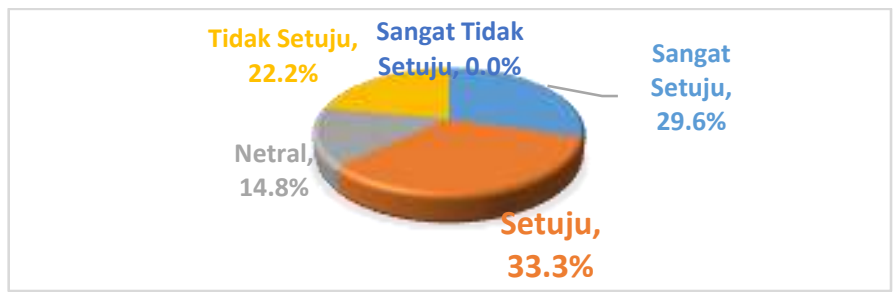

Grafik 1

Respon Masyarakat/Pengunjung pada Poster 1

Delapan belas orang responden memberikan respon positif dari poster 1, 4 orang responden bersikap netral dan hanya 6 orang yang memberikan respon negative. Berdasarkan hasil wawancara diperoleh data bahwa respon positif terhadap poster himbauan itu karena menggunakan icon yang mudah di mengerti oleh semua orang dan merujuk pada protokol kesehatan yang sesuai dengan aturan dari WHO, sehingga menarik minat responden untuk mengikuti himbauan poster tersebut. Respon negative diberikan karena menurut sebagian responden penggunaan bahasa Inggris pada poster 1, cukup sulit dipahami oleh sebagian umum orang terutama yang tidak mengerti bahasa Inggris.

2. Daya tarik poster 2

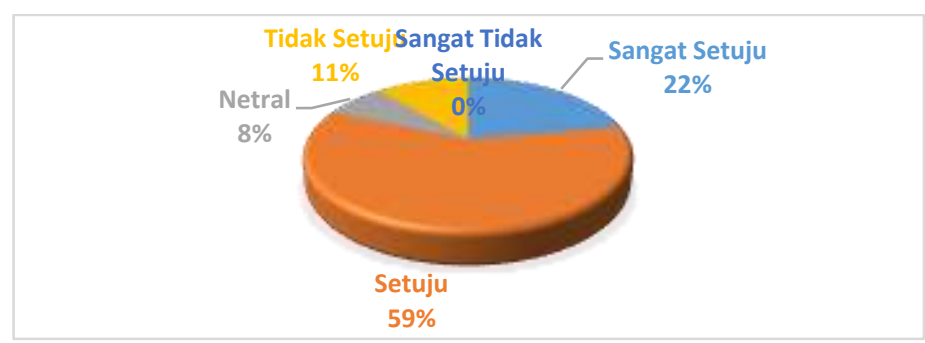

Grafik 2

Respon Masyarakat/Pengunjung pada Poster 2

Berdasarkan hasil survei diperoleh data 22 responden memberikan respon positif, 2 orang bersikap netral dan 3 orang memberikan respon negative. Respon positif diberikan karena penggunaan kata pada poster 2 cukup sederhana dan mudah dimengerti semua orang. Masyarakat juga berpendapat bahwa himbauan pada poster 2 sangat singkat dan sangat menarik mereka untuk mengikuti himbauan tersebut, terlebih lagi bagi wisatawan asing himbauan pada poster 2 sederhana dan tidak bertele-tele. 
3. Daya tarik poster 3 secara keseluruhan

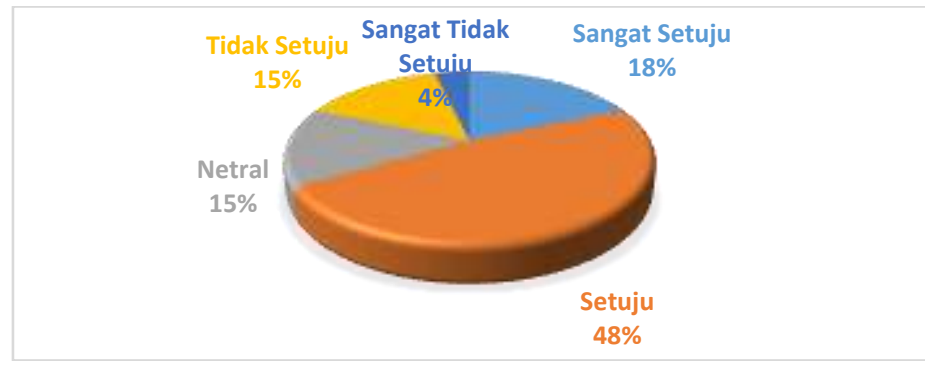

Grafik 3

Respon Masyarakat/Pengunjung pada Poster 3

Hasil survei Poster 3 menunjukan respon positif diberikan oleh 18 responden, 4 orang bersikap netral dan 5 orang memberikan respon negative. Respon positif diberikan karena penggunaan bahasa Indonesia dan dilanjutkan dengan istilah umum yang ada dalam protokol kesehatan di masa pandemi Covid-19, sehingga tetap mudah dipahami oleh masyarakat/pengunjung café/restoran tersebut. Masyarakat/pengunjung memberikan respon negative pada poster 3, dikarenakan menurut sebagian kecil responden, penggunaan bahasa dalam poster himbauan akan lebih baik jika menggunakan 1 bahasa saja, bahasa Indonesia atau bahasa Inggris.

4. Daya tarik poster 4 secara keseluruhan

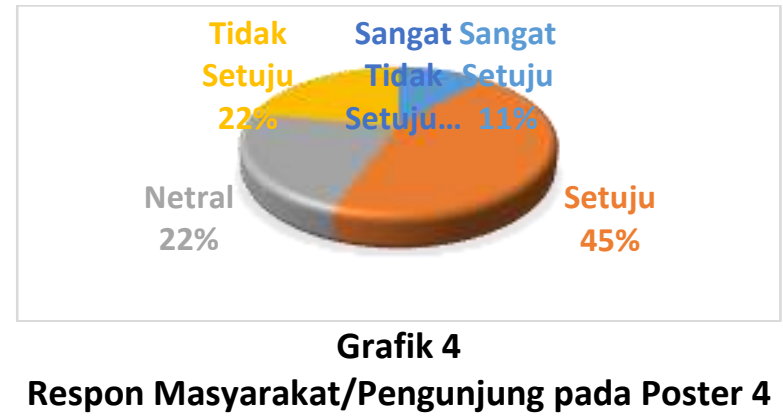

Lima belas orang responden memberikan respon positif, responden, 6 orang bersikap netral dan 6 orang memberikan respon negative. Respon positif diberikan penggunaan bahasa himbauan pada poster tersebut sangat jelas, walaupun menggunakan bahasa Inggris tetapi icon yang digunakan pada poster tersebut cukup membantu masyarakat/pengunjung untuk memahami himbauan yang disampaikan oleh poster 4. Dari hasil wawancara diperoleh informasi bahwa himbauan pada poster 4 kurang menarik minat responden, tidak seperti respon yang diberikan pada 
p-ISSN: 2301-5926 | e-ISSN: 2579 793X himbauan poster 1,2 dan 3. Sedangkan jika dilihat dari latar belakang pendidikan responden $81,4 \%$ memiliki tingkat pendidikan lebih dari SMA, informasi yg ditampilkan pada poster 4 menunjukkan keseriusan pihak pengelola café/restoran untuk menjalankan protokol kesehatan yang telah ditetapkan, karena informasi yang diberikan sangat detail. Akan tetapi hal itu tidak memberikan respon positif karena responden berpendapat pengunjung akan membutuhkan waktu yang lama untuk mencerna informasi yang di sampaikan pada poster 4 sedangkan bagi pengunjung wisatawan asing dirasa sudah paham akan protokol kesehatan.

\section{E. KESIMPULAN}

Berdasarkan hasil pengumpulan data poster himbauan terkait pandemic Covid-19 di pengelola kuliner yang berada di wilayah objek canggu, bahasa yang digunakan dominan menggunakan bahasa Inggris. Hal tersebut dikarenakan pengunjung/konsumen dari café/restoran tersebut mayoritas adalah wisatawan asing yang sedang berwisata atau menikmati keindahan objek wisata yang ada di daerah Canggu. Bahasa yang gunakan adalah bahasa Inggris yang sesuai kaidah gramatikal dalam bahasa Inggris. Jenis kalimat yang digunakan oleh semua poster himbauan adalah kalimat deklaratif dan kalimat imperative. Kalimat tersebut digunakan untuk mempengaruhi, membujuk dan mengingatkan pengunjung/konsumen industry kuliner untuk melakukan protokol kesehatan, sebagai salah satu usaha memutuskan rantai penularan Covid - 19. Selain itu juga pengelola kuliner menggunakan ikon dan mengaplikasikan warna agar tampilan visual dari poster himbauan tersebut dapat menarik pembacanya, dalam hal ini pengunjung café/restoran.

Hasil survei menunjukan bahwa penggunaan bahasa ruang public di industry kuliner yang menarik minat masyarakat/pengunjungnya untuk mengikuti himbauan pada poster tersebut jika bentuk himbauan sederhana dan mudah dipahami oleh semua kalangan. Penggunaan visual pada sangat membantu masyarakat untuk memahami infomasi yang disampaikan poster tersebut. Untuk penggunaan istilah-istilah baru yang muncul di saat pandemic Covid-19 yang dikeluaarkan oleh WHO ataupun pemerintah Indonesia, sangat berterima di masyarakat/pengunjung dan membantu mereka untuk menerapkan protokol kesehatan tersebut. 


\section{F. SARAN}

Masa pandemi Covid-19 sangat mempengaruhi banyak sektor, mulai dari industri pariwisata, perhotelan, jasa, kuliner dan sector lainnya. Bali yang mendapatkan pendapatan daerah terbesar dari sector pariwisata dan sector lain yang terkait, tidak lepas dari ketepurukan. Memasuki tatanan New Normal pemerintah menerapkan aturan ketat terkait protokol kesehatan yang bertujuan untuk memutus mata rantai penyebaran Virus Covid-19. Pemerintah mewajibkan seluruh bidang industry menerapkan protokol kesehatan, salah satunya dengan memberikan edukasi kepada masyarakat/pengunjung di industri kuliner seperti café/restoran berupa poster yang berisi himbauan tentang prokes. Berdasarkan hasil penelitian diperoleh beberapa factor yang perlu diperhatikan dalam menyusun atau membuat poster himbauan tentang prokes.

1. Pengunaan bahasa dalam poster diusahakan sederhana dan mudah di pahami oleh pembaca.

2. Bahasa yang digunakan dalam menyampaikan himbauan/informasi harus sesuai dengan target sasaran (masyarakat/pengunjung).

3. Penggunaan symbol/icon yang umum digunakan dalam protokol kesehatan Covid-19 WHO ataupun pemeruntah, sangat membantu pembaca untuk memahami informasi yang disampaikan.

4. Penggunaan istilah-istilah baru yang muncul dimasa pandemic, secara tidak langsung turut mengedukasi pembaca poster tersebut.

\section{DAFTAR PUSTAKA}

Aribowo, E. K., Rahmat, \& Arif Julianto Sri Nugroho. (2018). Studi Lanskap Linguistik Kota Surakarta dalam Mempertahankan Tiga Identitas. Semiloka Dan Deklarasi Pengutamaan Bahasa Negara, 1-8.

Budiman, K. (2011). Semiotika Visual: Konsep, Isu, dan Problem Ikonisitas. Jalasutraalasutra. Fatmahwati A, F. A. (2019). Penggunaan Bahasa Indonesia Pada Media Ruang Publik Di Kota Pekanbaru. Suar Betang, 13(2), 131-144. https://doi.org/10.26499/surbet.v13i2.76

Kementrian Pariwisata dan Ekonomi Kreatif, B. P. dan E. K. (2019). Laporan Kinerja Badan Ekonomi Kreatif 2109.

Pujianto, T. R., Vallery, V., \& Soetanto, C. (2021). Perancangan Kafe di Era New Normal, (April), 255.

Purwanto, D., \& Filia, F. (2020). Fungsi Strategis Bahasa Dalam Kegiatan Ekonomi: Sebuah Kajian Linguistik Lanskap Iklan Restoran Di Kota Pontianak. Literatus, 2(2), 123-132. https://doi.org/10.37010/lit.v2i2.82

Putra, M. R. A. L., Mahardhika, G. P., \& Putro, H. P. (2019). Penerapan Kemampuan Problem solving pada Siswa SMP Menggunakan PendekatPutra, M. R. A. L., Mahardhika, G. P., \& 
p-ISSN: 2301-5926 | e-ISSN: 2579 793X

Putro, H. P. (2019). Penerapan Kemampuan Problem solving pada Siswa SMP Menggunakan Pendekatan Computational Thinking ( CT ) Berbasis Role Play. Jurnal Format, 8(2), 158-164.

Rahmawati, Rahmah, S. F., Mahda, D. R., Purwati, T., Utomo, B. S., \& Nasution, A. M. (2020). Edukasi Protokol Kesehatan dalam Menjalankan New Normal di Masa Pandemik Melalui Media Poster. Seminar Nasional Pengabdian Masyarakat LPPM UMJ, 1-5. Retrieved from http://jurnal.umj.ac.id/index.php/semnaskat

Ramadeni, S., \& Soewardikoen, D. W. (2017). Identitas Visual Dan Media Promosi Wisata Edukasi Jendela Alam. Desain Komunikasi Visual, Manajemen Desain Dan Periklanan (Demandia), 113. https://doi.org/10.25124/demandia.v2i01.767

Subadra, I. N. (2021). Pariwisata Budaya dan Pandemi Covid-19: Memahami Kebijakan Pemerintah dan Reaksi Masyarakat Bali. Jurnal Kajian Bali (Journal of Bali Studies), 11(1), 1. https://doi.org/10.24843/jkb.2021.v11.i01.p01

Suktiningsih, W. (2017). Language Choice Amongs Teenager Etnic Sasak Mataram. RETORIKA: Jurnal Ilmu Bahasa, 3, 211-219. https://doi.org/10.22225/jr.3.2.334.211-219

Utama, I., Suamba, I. B. P., Sumartana, I. M., Waruwu, D., \& Krismawintari, N. P. (2020). Dampak Himbauan Social Distancing Dalam Mengurangi Penyebaran Covid-19 Pada Masyarakat Bali. Jurnal Aplikasi Dan Inovasi Iptek, 2(1), 46-59. Retrieved from https://jasintek.denpasarinstitute.com/index.php/jasintek/article/view/48

Widani, N. N., \& Suktiningsih, W. (2020). Entitas Wisatawan Asing Terhadap Kemampuan Berbahasa Inggris Masyarakat Lokal Banjar Tegal Gundul, Desa Tibubeneng Kuta Utara , Badung, Bali. Humanitatis : Journal of Language and Literature, 6(2), 273-296. https://doi.org/https://doi.org/10.30812/humanitatis.v6i2.806

Zahrulianingdyah, A. (2018). Kuliner sebagai pendukung industri pariwisata berbasis kearifan lokal, 6(1), 1-9. 